\title{
Does Islamic Interbank Rate Influence Bank Characteristics and Economic Cycle in Malaysian Monetary Transmission?
}

\author{
Fidlizan Muhammad \\ Department of Economics, Faculty of Management and Economics \\ Education University of Sultan Idris, Tanjong Malim, Perak, Malaysia
}

\begin{abstract}
Azam Sulaiman Mohamad
Department of Syariah and Economics, Academy of Islamic Studies, University of Malaya, Kuala Lumpur, Malaysia
\end{abstract}

Mohd Yahya Mohd Hussin

Department of Economics, Faculty of Management and Economics

Education University of Sultan Idris, Tanjong Malim, Perak, Malaysia

Azila Abdul Razak

Department of Economics, Faculty of Management and Economics

Education University of Sultan Idris, Tanjong Malim, Perak, Malaysia

Received: May 17, $2012 \quad$ Accepted: July 29, $2012 \quad$ Published: December 1, 2012

doi:10.5296/ajfa.v4i2.1813ＵRL: http://dx.doi.org/10.5296/ajfa.v4i2.1813

\begin{abstract}
This study aims to determine the effectiveness of Islamic Interbank Rate as the intermediary target by monetary policymakers in achieving economic goals. Via Islamic banking institutions as the mediator to channel the policy effect, the relevancy of this tool is identifiable. To attain this objective, a credit channel model was used by adapting macroeconomic variables and also bank specific variables. Data from 1997 until 2010 was regressed by using the Panel Data method with the application of interaction approach. The
\end{abstract}


analysis finding shows that the IIR is capable in influencing the bank specific variables. accordingly, Islamic banks are the significant intermediaries in ensuring the effect of policy implementation provides stimulation to the achievement of the desired economic goals. Besides, the significant pro cyclical nature through the interaction with the GDP, indicates the effect of this policy tool in influencing bank behavior to offer financing for the economic sectors parallel to the current economy.

Keywords: Islamic Banking Financing, Islamic Interbank Rate, Bank Characteristics, Economic Cycle, Panel Data 


\section{Introduction}

The central bank plays a fundamental role in managing the financial system stability of a country. In operating its function, the central bank has various approaches that can be applied as widely discussed in the financial economic studies. There are two forms of financial policy intermediary target used by the central bank to achieve this objective which are the financial aggregate target and also interest rate target. Based on these targets, the debate among the economists especially between the Keynesian and Monetarists involves the extent of bank role as intermediary in this channel. However, between these two forms of channel, it has been found that the interest rate target channeled through bank intermediary was given priority in much research. Thus, this monetary policy transmission is known as the credit channel. A study by Bernanke (1983) and Bernanke and Blinder (1988) regarding the economic crisis in the United State of America known as the Great Depression was the first preliminary study that discovered the importance of this channel. Investigation by using the bank specific variables was then applied in getting a more detailed evidence for the credit channel efficiency. The specific variables studied consisted of bank size (Kashyap and Stein,1995), bank liquidity (Kashyap and Stein, 2000) and also bank capital (Kishan and Opiela,2000). While the current research has also been adopting the credit risk variables for the purpose of demonstrating the actual performance of a bank financial status (Altunbas, Gambacorta and David, 2010; Rajan, 2005; Borio and Zhu,2008).

Following the importance of this credit channel in the implementation of financial policy, similar studies have also been conducted in other countries. Among them are Altunbas, Fazylov and Molyneux (2002) and Pizarro-Barcelo (2009) in the European countries, Nertherlands (de Haan, 2001), Greece (Brissimis, Kamberoglu and Simigainnis, 2001), Portugal (Farinha and Carlos, 2001), Japan (Ogawa,2000), Italy (Gambacorta and Mistrulli,2004) and many more.

As many studies were seen as subscribing to this credit channel, hence the same objective must be researched in Malaysia. The scenario in Malaysia is of the interest to be studied for two reasons. Firstly, the Bank Negara Malaysia (BNM) which acts as the responsible institution in managing the country financial target, has changed its financial policy mediating target from the financial aggregate target to the interest rate target in 1990's (BNM, 1999). This target is still being implemented until today (BNM, 2010). Secondly, the dual banking practice that are Islamic and conventional banking systems which have been in operation simultaneously since the past three decades. Based on the principles of banking operation that need to comply to the Shariah requirement, the Islamic Interbank Money Market has been established to enable the transaction of fund surplus and deficit between institutions can be carried out. In the meantime, this market is used by the BNM to operate its function in achieving the stability goal in the money market and economic goals. Therefore, how far does the managed financial policy tool in this market function to the achievement of basic financial goals will be investigated in this study.

The discussion of this study is arranged in such way; Section 2 explains on the financial policy and development of Islamic banking system in Malaysia. Data, variables and research 
methodology used in the regression model is elaborated in section 3 . In section 4, the discussion proceeds on the outcome of analysis. While the section 5 summarizes the findings of analysis and its implication.

\section{Development Of Islamic Banking And Financial Policy In Malaysia}

Islamic banking system has rooted in Malaysia for almost three decades. In this period, its operation is executed concurrently with the conventional banking system. Although the age of the Islamic banking in Malaysia is still green, from the aspect of growth it is outstanding. This development conforms to the growth of Islamic finance at global. The asset of the world Islamic financial system currently has surpassed USD 1 trillion and recorded annual growth of $20 \%$. This is in line with the forecast by Zaher and M. Kabir (2001) who estimated that Islamic banking is capable to dominate between 40 to 50 percent from the total of saving or deposit by the world Muslim community in 2010.

In Malaysia, the Islamic banking system commenced from the year 1983 with the establishment of the first Islamic bank which is the Bank Islam Malaysia Berhad (BIMB). Its years of operation for 10 years without competitors demonstrated a positive level of asset development and financing. This situation implied that this sector has a potential to be developed. After 10 years, the deposit of Islamic banking reaches the total of RM1.6 billion, while the total of financing nears to RM1 billion.

Accordingly, the BNM expanded the Islamic banking system by creating the interest free banking system in 1993. Through this system, the conventional banking system was allowed to to create its Islamic Windows operation to to carry out its banking operation based on Shariah principles. Based on the number of branches and good institution infrastructure, the implementation of this system has given a lot of advantages to the competitiveness of Islamic banking in Malaysia. As a result, the total of deposit and financing of Islamic banking system is increasing year by year. The total of deposit rose from RM 26 billion in 1998 to RM218 billion pada in 2010. Similar statistics is also shown in the booming total of financing from RM11.7 billion to RM162 billion during the same period.

As a comparison in the growth of financing, Islamic banking financing reveals a higher growth rate compared to the conventional banking loans. The islamic banking system recorded a two digit value of growth in 2000 until 2010. In these 5 years period (2005-2010), the average of its financing growth was as much as $17.5 \%$ compared to $7 \%$ in the conventional banking. Entailing to the capability of Islamic banking in competing in this market, the BNM increased the dominating figure of Islamic banking market by 5\% in 2000 to $20 \%$ in 2010 and $40 \%$ in 2020.

Due to rapid expanding of the Islamic banking in Malaysia, the central bank regulation of these institutions is essential to achieve stability in financial markets. This scenario is compatible with the economic dependence on bank loans capital that are steadily increasing. The ratio between bank loans with a total Gross Domestic Product (GDP) in Malaysia in 2000 was 127\%. It then increased to $158 \%$ in 2010 . According to Alloway (2009), this ratio could trigger a crisis 
if it is not regulated by prudence, as happened in other European countries now. In the Islamic banking, this ratio was also increasing by $12 \%$ in 2000 to $29 \%$ in 2010 .

Accordingly, in attaining the objective of financial stability that will stimulate economic goals, policy makers need to implement the strategic target policy that is able to influence the bank's lending activities. To achieve this purpose, BNM has adapted the policy of targeted strategies from the monetary aggregates target to the interest rate target in the mid 90s. This change is timely because of the economic sectors appear more sensitive to changes in interest rates compared to interest rates of treasury banking.

In carrying out its interest rate target for the Islamic banking sector, BNM has established the Islamic Interbank Money Market (IIMM) in 1994. Through this market, the surplus and deficit that occurs in institutional funds were traded between institutions based on Shariah principles and the agreed funding rate. The applicable rate in the market was known as the interbank rate (Islamic Interbank rate). This rate was also the target policy tool by the BNM in implementing the financial transmission of Islamic banking institutions. Dramatic growth in this market was shown which recorded the increased value of transactions by almost 10 times between 1999 to 2010. Value of transactions in this market in 2010 was RM2, 552 billion. This significant growth of transactions between the bank shows that the economic capital financing offered is in line with economic growth in Malaysia. This relationship shows that the nature of the economic cycle affects banks in providing financing.

Parallel to the development of Islamic banking and monetary policy as practiced in Malaysia, its effect on the appropriate financing is duly to be examined. In other sense, the financing of the Islamic banking sector, is likely to respond differently to the implemented monetary policy. This is because, the operation of Islamic banking is based on asset compared to conventional banking that is based on money alone. This result in the lower risk of Islamic banking compared to the conventional banking. However, this practice of dual banking does not exclude the Islamic banking to face the risk of interest rates that can influence the institution financial assets status.

\section{Data and Methodology}

In this study, annual data from 1997 to 2010 was used. A total of seven variables were employed in this credit channel model. It covers five specific variables, namely the number of bank financing (TF), bank size (SZ), liquidity (LIQ), capital (CAP) and credit risk (RISK) and the two macro variables of the Gross Domestic Product (GDP) and Islamic interbank rates (IIR).

The efficiency of the Islamic interbank rate (IIR) to function as an instrument of monetary policy transmission mechanism was analyzed by using the model in offering loans that have been used in many previous studies such as Kashyap and Stein (1995), Kishan and Opiela (2000) and de Haan (2003). In these studies, bank size, liquidity and capital are the variables that can be used in evaluating the efficiency of the transmission of policy on bank lending. Meanwhile, a study by Ehrmann, Gambacorta, Jorge, Sevestre and Worms (2001), Keys, Mukherjee, Seru and Vig (2008), Aricci, Igan and Laeven (2008) and Altunbas et al. (2010) 
have included the credit risk variables in this model. These important variables were included together in the analysis model for the justification of innovation in the financial markets and the availability of facilities to transfer the credit risk is expected to have a tendency to eliminate the actual information on the financial performance of banking institutions (Borio and Zhu, 2008; Instefjord, 2005).

In relation to that, the estimation model in this study can be written briefly in the following equation (1):

$$
\Delta T F_{i, t}=\alpha_{i}+\beta_{1} \Delta Y_{t}+\beta_{2} I I R_{t}+\beta_{3} X^{\prime s}{ }_{i, t-1}+\beta_{4} I I R^{*} X^{\text {'s }}{ }_{i, t-1}+\beta_{5} I I R^{*} \Delta Y_{t}+\varepsilon_{i t}
$$

with, $\mathrm{i}=1, \ldots \mathrm{N}$ and $\mathrm{t}=1, \ldots \mathrm{T}$. Both of these subscripts refer to the number of institutions and period of time. Based on equation (1), $\Delta T F$ which represents the amount of financing Islamic banks is regressed with real GDP growth as a control variable for controlling the change in loan demand. According to Kashyap and Stein (1995), better economic situations increase the economic sectors profitable in terms of expected net present value, thereby increasing the demand of credit. The introduction of this variable captures cyclical macroeconomic movements and serves to isolate the monetary policy changes.

In this model, four bank specific variables are used to measure bank responses to changes in monetary policy. These variables are bank size (SZ), liquidity (LIQ), capital (CAP) and credit risk (RISK). Three variables (SZ, LIQ and CAP) are a standard variable that is often used by researchers to test the credit channel (Kashyap and Stein, 1995; Stein, 1998; Kishan and Opiela, 2000; Van den Heuvel, 2002). Current research is also included with the RISK variables in the model to show a more comprehensive effect. TF variables, GDP and SZ in this study are in the form of logs, while LIQ, CAP and RISK are as a ratio to total assets. In addition, all bank-specific characteristics refer to $t-1$ in order to avoid endogeneity bias.

In testing the efficiency of this channel, the researchers suggested the use of interactive methods. This interaction variable is the variable that shows the effects of monetary policy on bank specific characteristics. Coefficient for this variable will show the form of behavior or the banks behavior in providing loans in response to the implemented monetary policy shocks (Golodniuk, 2006; Hosono, 2006). The bank characteristics were furthermore interacted with the monetary policy indicator to find out if monetary shocks have distributional effects on financing in Malaysian Islamic banking institutions. The hypothesis is that small size, less liquidity, poorly capitalized and higher credit risks banks will react more strongly to monetary policy indicators changes.

Meanwhile, to test the nature of economic cycles in the supply of bank financing, the interaction between economic growth and policy tools was adopted. The hypothesis tested is the small banks which show greater response to economic changes. By this hypothesis, monetary policy contraction or increases in the interest rates will have a stronger impact on small banks. Therefore, panel data approach was deployed in this study. Wooldridge (2002) defines panel data as the data that has both cross-sectional and time-series dimension. In this study, the cross-sectional units are the Islamic banking institutions in Malaysia. 


\section{Macrothink}

To perform the analysis of the equation (1) model, selection of appropriate analytical method is important. Two main methods are often discussed in the analysis of panel data regression using the method of least squares (OLS) or Generalized Least Squares method (GLS). To find a suitable method, test specifications performed, including correlation tests, heteroscedasticity (White 'general test) test and autocorrelation (Wooldridge test). Data that is not normally distributed in the correlation test is an early indication of the choice of GLS methods as the appropriate analytical methods. Through the heteroscedasticity tests that reject the null hypothesis, it is able to prove that the GLS method as the best method (Gujarati, 2003). If the null hypothesis in the autocorrelation test is rejected, then the regression model must take into account the terms of the first degree autoregressive (AR1) (Wooldridge, 2002).

Once the results of the regression had been obtained, then the diagnostic test was done. This test is to ensure that the results of econometric estimation is to meet the criteria. Heteroscedasticity tests performed using Breush Pagan test or Lagrange (LM), while tests LBI (locally best invariant) was to test the autocorrelation problem. This test was developed by Baltagi and Wu (1999) to allow testing for serial correlation in the form of unbalanced panel data is done. According to Greene (2008), if this diagnostic test reject the null hypothesis, then the estimation model is proposed to be regressed in dynamic form.

\section{Result of Analysis}

The result of model specification test found that the method of GLS with AR1 error term is an appropriate method of analysis to be used to test the efficiency of this transmission channel. It is derived based on the unbalanced data distribution for all variables used. In addition, the null hypothesis in heteroscedasticity test and autocorrelation were also successfully rejected. Therefore, the discussion in the analysis is based on the results of analyzes using GLS AR (1).

Before the estimation is carried out on the credit channel model, it is important to test the significant level of Islamic interbank rate (IIR) as a tool of monetary policy transmission. To find this relationship, the method of response function (impulse response function, IRF) in the VAR model was applied. This reaction is shown in Figure 1 below. 


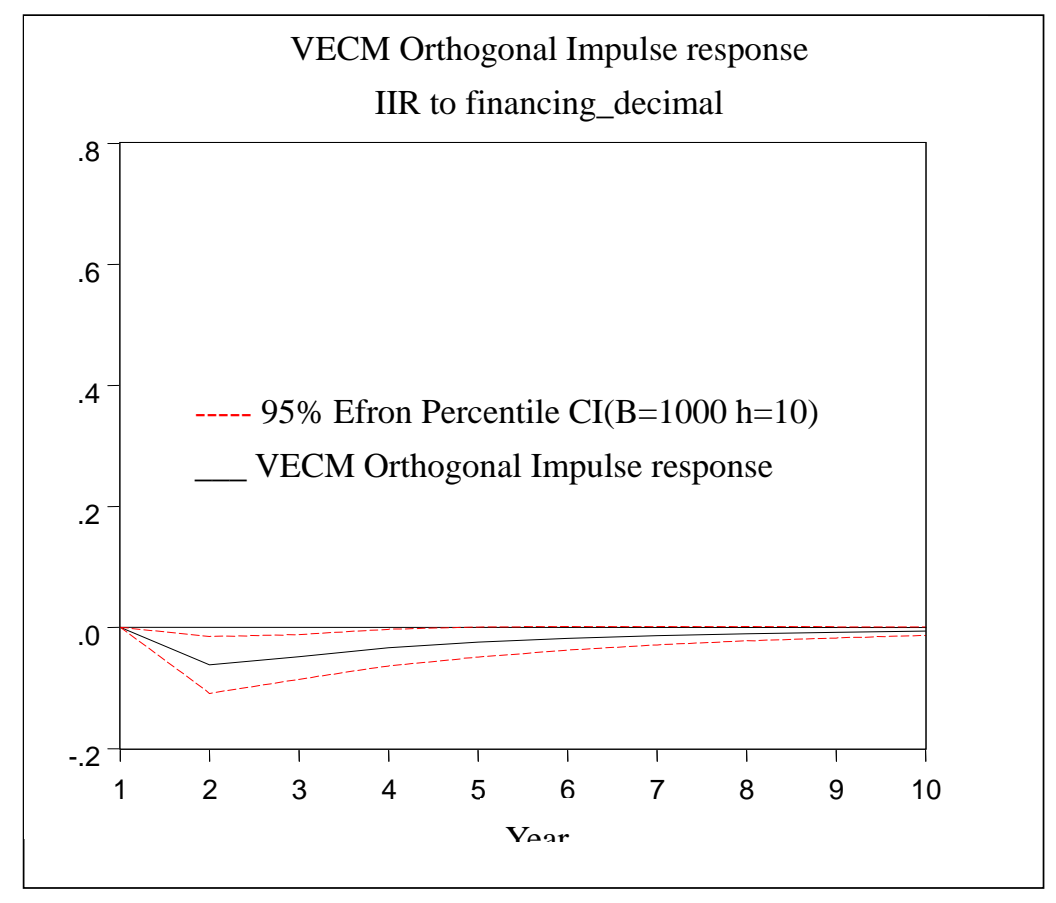

Figure 1. Impulse Response

Based on Figure 1, it was found that the impact of shock in the monetary policy through the IIR changes gave negative impact on the total supply of bank financing for a period of one year. This effect gradually decreases in further. This is consistent with the expected effects of monetary policy on investment and consumption patterns of economic sectors. In conjunction with these findings, further analysis can be done to evaluate the extend of this rate to affect bank institutions. The analysis shown in Table 1. 


\section{Mll Macrothink}

Table 1. Regression Result

\begin{tabular}{ll}
\hline Variable & Coeficient (s.e) \\
\hline $\begin{array}{l}\text { Constant } \\
\Delta G D P\end{array}$ & $-0.1440(1.6544)$ \\
$\underline{\text { Policy Tool }}$ & $0.0108(0.0092)$ \\
IIR & \\
Bank Specific Characteristics & $-0.04479(0.0970)$ \\
SIZE & $-0.0137(0.1069)$ \\
CAP & $-2.0270^{*}(0.5917)$ \\
LIQ & $1.5205^{* * *}(0.8123)$ \\
RISK & $1.4687^{*}(0.3574)$ \\
& \\
Interaction variables & \\
ISIZE & $-0.0437(0.0335)$ \\
ICAP & $0.8340^{*}(0.1315)$ \\
ILIQ & $-0.2032^{* * *}(0.1226)$ \\
IRISK & $-0.8410^{*}(0.1322)$ \\
IKDNK & $-0.0668^{* *}(0.0337)$ \\
\hline Adjusted R2 & 0.3589 \\
Wald Test $\left(\chi^{2}\right)$ & $92.43^{*}$ \\
D-Watson Test & \\
Baltagi-Wu & 1.7331 \\
LM Test & 1.9912 \\
VIF & 2.42 \\
\hline
\end{tabular}

$*, * *, * * *$ significant at $1 \%, 5 \%$ and $10 \%$

Based on Table 1, the GDP variable and the IIR were not significant. This insignificant relationship particularly between IIR and TF in this model is interesting to be examined. This finding is consistent with several previous studies such as Kohler, Hommel and Grote (2005), Rania and Billmeier (2007) and Era and Floerkemeier (2006). Justification for this condition may be associated with the implementation of monetary policy in Malaysia itself. It is premised on the conventional interbank rates is better known than this IIR. In addition, the reality of practice in policy management for Islamic banking is to make conventional interest rate as a benchmark (benchmarking) in forming a competitive Islamic interbank rate (IIR). In other words, the conventional rate is still a precursor indicators (leading indicators) to the Islamic interbank money market in Malaysia at present. This is appropriate given that the market share of Islamic banking in the financial system in Malaysia is still small at only $20 \%$. The insignificance of GDP variable is probably related to the slow growth of Malaysian economy due to the Asian economic crisis and a few global economic crises occurred 
afterwards. The implementation of open market will incur economic shock and it will also give the same effect to the domestic economy. Concurrently, it will also implicate the demand of loans from banking institutions.

For bank specific variables, it was found that three variables are significant. Two of these specific features demonstrated a positive coefficient value of the variable LIQ and RISK, while the CAP variables showed a negative coefficient values. The results from these studies indicate the existence of specific features of the distribution effects on the supply of bank financing. For variables with positive coefficient, it indicated that an increase in liquidity and credit risk reduction can improve the ability of banks to increase the amount of funding. Whereas, for negative coefficient variables showed that banks in total liquidity shock, affect the reduction in the total supply of financing.

The main empirical evidence for the evidence of Islamic financing channel is shown by the positive coefficient on the variable LIQ (Bernanke and Blinder, 1988; Bernanke and Gertler, 1995; Farinha and Carlos, 2001). This is because a lot of obtained bank liquidity from the deposit will affect the supply of loans to meet capital demand by economic sector for investment or consumption. Shocks or changes in monetary policy will affect the resources to this sector. The implication, in short, bank institutions are assumed to have difficulty to source a replacement. This situation in turn will affect the bank's financial capacity and have a direct impact on the supply of bank financing to the economic sector.

Based on the analysis, it can be concluded that the bank specific characteristics are important to explain the financial structure of a bank institution. Therefore, these specific features are suitable to explain the role of the bank to channel the monetary policy transmission impact on the economy. Thus, all four of these variables were interacted with the policy tool that is the IIR variable to prove the efficiency of this policy transmission. Meanwhile, to assess the extent of this IIR functions as a signal to economic changes will be derived through IIR variable interaction with the GDP.

The result of the interaction of these five variables with the policy tool is shown in Table 1. Based on the analysis, it was found that the effect of monetary policy was channeled into the economy immediately by the banks that have a high level of credit risk and liquidity of the small banks. This scenario can be explained as follows. Changes in monetary policy rate will have implications on the debt obligations incurred by economic sector. This resulted in bank institutions to be exposed to risk and in turn affect its ability to supply a larger financing. In addition, it appears that small banks with low liquidity value also showed an immediate response of monetary policy shocks. Available financing offerings contracted at $0.20 \%$ following the increase in this rate would make massive amounts of deposits of Islamic banking to conventional banking profit. This situation will affect the position of the financial portfolio of the institution. This effect further reduces the capacity of institutions of Islamic banks to increase the number of financing offer.

Meanwhile, the capital of the interaction showed a positive effect. This clearly shows that the effect of financial transmission policies through banks with large capital is slower. This finding is consistent with the study by Kishan and Opiela (2000) who find that banks with large capital 
would show a slow response to shocks policies implemented by policy makers. Result of the interaction with the GDP shows that the nature of the financing offer is based on the economy (Matsuyama, 2007; Stein, 1998). Fluctuations in the economy will encourage policy makers to make changes to the policy tool. This rate change is symbolic or a signal to financial institutions related to the occurring economic scenario. Result of this analysis indicated that the transmission effects of monetary policy changes on the economy is shown immediately by small banks.

Based on analysis of discussion on the findings in Table 1, it can be concluded that the monetary policy instruments created by BNM through IIMM is able to influence a bank for purposes consistent with the implementation of a monetary policy. Small banks are immediately available to respond to these policy changes. In addition, it appears that this tool will be the signals to the players in the Islamic financial market to the current economic scenario and a significant medium for the transmission of monetary policy implemented by the BNM.

\section{Conclusion}

This study discusses the effectiveness of the monetary policy rate instrument executed in the Islamic interbank money market to influence the banking institutions to achieve the set economic goals. By using the Islamic interbank rate as an instrument of policy objectives, this rate effectively influence the institution of Islamic banks, especially banks that have high rates of credit risk and lower liquidity value. In addition, this rate was also found effective to induce banks to offer financing amount in accordance with the current economic scenario. The overall findings of this study was found to support the hypothesis of the credit channel as the transmission mechanism of financial policy in Malaysia. Therefore, the implementation of the credit channel of monetary policy as a mechanism involving Islamic banking institutions is efficient.

\section{References}

Alloway, T. (2009). Something is rotten in the state of Denmark, and Ireland and Spain, Financial Times, September.

Altunbas,Y., Fazylov, O., dan Molyneux,P. (2002). Evidence of Bank lending channel in Europe. Journal of Banking \& Finance, 2093-2110. http://dx.doi.org/10.1016/S0378-4266(02)00201-7

Altunbas,Y., Gambacorta, L. and David M.I. (2010). Bank Risk and monetary policy. Journal of Financial Stability, 6, 121-129. http://dx.doi.org/10.1016/j.jfs.2009.07.001

Bernanke, B. S. (1983). Nonmonetary Effects of the Financial Crisis in the Propagation of the Great Depression. The American Economic Review, 73(3), 257-276.

Bernanke, B. S. and Blinder, A.S. (1992). The federal funds rate and the channels of monetary transmission. American Economic Review, 82(4), 901-921. 
Bernanke, B. S. and Blinder, A.S. (1998). Credit, Money and aggregate demand. American Economic Review, 78(2), Papers and proceedings of the One-Hundredth Annual Meeting of the American Economic Association, 435-439.

Bernanke, B. S., and Gertler, M. (1995). Inside the Black Box: The Credit Channel of Monetary Policy Transmission. Journal of Economic Perspectives, 9, 27-48. http://dx.doi.org/10.1257/jep.9.4.27

Borio, C. and Zhu H. (2008). Capital Regulation, Risk-Taking and Monetary Policy: A Missing Link in the Transmission Mechanism?. BIS Working Papers, No. 268.

Brissimis, S.N., Kamberoglu, N.C and Simigainnis, G.T. (2001). Is there are bank lending channel of monetary policy in Greece Evidence from bank level data. European Central Bank Working Paper Series No. 104, 1-29.

Central Bank of Malaysia. (2000). Annual Report 2000, Kuala Lumpur: Central Bank of Malaysia.

Dale, S., and Haldane G. A. (1995). Interest Rates and the Channels of Monetary Transmission: Some Sectoral Estimates. European Economic Review, 39(9), 1611-1626. http://dx.doi.org/10.1016/0014-2921(94)00108-1

de Haan, L. (2003). Microdata evidence on the bank lending channel in Netherlands. De Economists, 151(3),293-315.

Dell' Ariccia, G., Igan, D., and Laeven, L. (2008). Credit Booms and lending standards: evidence from subprime mortgage markets. CEPR Discussion Papers, No. 6683.

Ehrmann, M., Gambacorta, L., Jorge M.P., , Sevestre, P., and Worms, A. (2001). Financial Systems and the role of banks in monetary transmission in the euro area. Discussion Paper 18/01, Economic Research Centre of Deutsche Bundesbank, Frankfurt, Germany.

Era, D.N. and Floerkemeier,H. (2006). Transmission Mechanism of Monetary Policy in Armenia: Evidence from VAR analysis. IMF Working Paper, WP/06/248

Farinha, L., and Carlos, R. M. (2001). The Bank Lending Channel of Monetary Policy: Identification and Estimation Using Portugese Micro Bank Data. ECB Working Paper 102, Frankfurt: European Central Bank.

Golodniuk, I. (2006). Evidence of bank lending channel in Ukraine. Research in International Business and Economics, 20,180-199.

Green, W.H. (2008). Econometric Analysis, 6th ed., Pearson.

Hosono, K. (2006). The transmission mechanism of monetary policy in Japan: evidence from banks' balance sheets. J. Japanese Int. Economics, 20, 380-405. http://dx.doi.org/10.1016/j.jjie.2005.07.003

Instefjord, N. (2005). Risk and hedging: Do credit derivatives increase bank risk?. Journal of Banking and Finance, 29,333-345. http://dx.doi.org/10.1016/j.jbankfin.2004.05.008 


\section{Macrothink}

Asian Journal of Finance \& Accounting

ISSN 1946-052X

2012, Vol. 4, No. 2

Kashyap, A.K., and Jeremy C.S. (1995). The impact of monetary policy on bank balance sheet. Carnegie-Rochester Conference Series on Public Policy, 42, 151-195. http://dx.doi.org/10.1016/0167-2231(95)00032-U

Kashyap, A.K., and Jeremy C.S., (2000). What do a Million Observations on Banks Say About the Transmission of Monetary Policy. American Economic Review, 90(3), 407-428. http://dx.doi.org/10.1257/aer.90.3.407

Keys, B., Mukherjee, T., Seru, A. and Vig, V. (2008). Did securitization Lead to Lax Screening? Evidence from subprime loans 2001-2006. Mimeo.

Kishan, R.P., and Opiela T. P. (2000). Bank Size, Bank Capital and the Bank Lending Channel. Journal of Money, Credit, and Banking, 32(1), 121-141. http://dx.doi.org/10.2307/2601095

Kohler, M., Hommel, J., and Grote, M. (2005). The role of banks in the transmission of monetary policy in Baltics. Discussion Paper, No. 06-005, Centre for European Economic Research

Matsuyama, K. (2007). Credit Traps and Credit Cycles. American Economic Review, 97, 503516. http://dx.doi.org/10.1257/aer.97.1.503

Rania al-Mashat and Billmeier A. (2007). The Monetary Transmission Mechanism in Egypt. IMF Working Paper, WP/07/25.

Schmitz, B. (2003). What Role Do Banks Play in the Monetary Transmission in EU Accession Countries. Discussion Paper, Centre for European Integration Studies (ZEI), Bonn, Germa.

Stein, J. C. (1995). An Adverse Selection Model of Bank Asset and Liability Management with the Implications for the Transmission of Monetary Policy. NBER Working Paper, No. 5217

Torben W. H., and Kempa, B. (2009). The credit channel in U.S. economic history. Journal of Policy Modeling, 31(1), 58-68. http://dx.doi.org/10.1016/j.jpolmod.2008.08.004

Van den Heuvel, S.K. (2002). Does Bank Capital Matter for Monetary Policy Transmission?. Federal Reserve Bank of New York Economic Policy Review, May.

Wooldridge, J.M. (2002). Econometric Analysis of Cross Section and Panel Data, Cambridge Massachusetts: The MIT Press.

Zaher, T. S., and M. Kabir Hassan (2001). A comparative literature survey of Islamic finance and banking. Financial markets, Institutions \& Instruments, 4(10), 155-199. http://dx.doi.org/10.1111/1468-0416.00044 